\title{
Lubrication Performance of Connecting-Rod and Main Bearing in Different Engine Operating Conditions
}

\author{
Jun Sun ${ }^{1 *} \mathbb{D}$, Biao Li², Shaoyu Zhu' ${ }^{1}$, Enming Miao ${ }^{3}$, Hu Wang $^{2}$, Xiaoyong Zhao ${ }^{2}$ and Qin Teng ${ }^{1}$
}

\begin{abstract}
Only the lubrication performance at rated engine operating condition was generally analyzed in current design and research of engine connecting-rod and main bearing. However, the actual engine (especially vehicle engine) does not always operate in rated operating condition and its operating condition changes constantly. In this paper, a fourstroke four-cylinder engine is taken as the studying object, the load and lubrication of connecting-rod and main bearing in different operating conditions are analyzed. The load of connecting-rod bearing is calculated by the dynamic calculation method, the loads of all main bearings are calculated by the whole crankshaft beam-element finite element method, and the lubrication performance of connecting-rod and main bearings are analyzed by the dynamic method. The results show that there are major differences in the changes and numerical value at corresponding moment of the loads and lubrication performance of connecting-rod and main bearings in an engine operating cycle in different engine operating conditions; the most unfavorable case of the lubrication performance of connectingrod and main bearings may not take place in the rated engine operating condition. There are also major differences between the lubrication performance of connecting-rod bearing and that of main bearing and between the lubrication performances of main bearings one another. Therefore, it will not be reasonable that the lubrication performance of a certain connecting-rod bearing or main bearing is analyzed in the design of the engine bearing. It is necessary to analyze simultaneously the lubrication performances of all bearings in different engine operating conditions.
\end{abstract}

Keywords: Lubrication, Connecting-rod bearing, Main bearing, Engine, Operating condition

\section{Introduction}

The connecting-rod or main bearing is one of main frictional pairs in engine. The operating condition of connecting-rod or main bearing affects directly the operational economy, reliability, durability and lifetime of engine. The capability and rationality of design are one of most essential factors to determine the performance of connecting-rod or main bearing. By the unremitting efforts of researchers and the progress of correlation technique, current design capability of engine connecting-rod and main bearing is improved continually, the factors considered in the design calculation of bearing

\footnotetext{
*Correspondence: sunjun_hfut@163.com

${ }^{1}$ School of Automotive and Transportation Engineering, Hefei University of Technology, Hefei 230009, China

Full list of author information is available at the end of the article
}

are perfected increasingly, and the performance of bearing is predicted more accurately. Many researches on the lubrication of connecting-rod or main bearing have been done. For example, Liu analyzed the transient tribodynamic performance of crankshaft-main bearing system in engine starting up [1]. Zammit investigated the lubrication of crankshaft bearing during engine warm-up [2]. Inui, Jia and Galera et al. [3-5] studied the factors affecting the lubrication of crankshaft bearing. Gu et al. [6] researched the performance of textured crankshaft bearing during an engine cycle. Mohammadpour, Mahdi, and Liu et al. [7-9] analyzed the effect of cylinder deactivation on the tribo-dynamic-acoustic and thermo-hydrodynamic characteristics of crankshaft bearing. Francisco, Lavie and Zhang et al. [10-12] studied the optimization of crankshaft bearing lubrication. Ozasa et al. [13] proposed a simplified estimation method of engine bearing 
lubrication. Shahmohamadi et al. [14] analyzed the mixed thermo-hydrodynamic lubrication of engine connecting rod bearing. Refs. [15-18] study the thermo-elastohydrodynamic lubrication of engine crankshaft bearing. Tabrizi et al. [19] compared three kinds of simulation models of connecting rod bearing. Zhang et al. [20] researched the mixed lubrication performance of high power-density engine main bearing. Toshihiro et al. [21] analyzed the lubrication of gasoline engine connecting rod bearing. $\mathrm{Bi}$ and Chen et al. [22,23] studied the lubrication of turbocharged engine main bearing. Choi et al. [24] analyzed the dynamically bearing elastohydrodynamic lubrication considering multi-flexible-body dynamics. Wei et al. [25-27] investigated the thermo-elasto-hydrodynamic mixed lubrication of marine engine main bearing. Shao et al. [28] analyzed the lubrication performance of engine main bearing coupling cylinder block and crankshaftconnecting rod system. Zhao et al. [29] analyzed the lubrication performance of marine engine main bearing in typical operating conditions. Yang et al. [30] analyzed the lubrication of gasoline engine main bearing considering transient heat transfer. However, only the lubrication performance of connecting-rod and main bearing in rated engine operating condition was generally analyzed in current design and research. In actual use, the engine (especially used in vehicle) does not always operate in rated operating condition and its operating condition changes constantly. Therefore, it is necessary to study the lubrication performance of engine connectingrod and main bearing in different operating conditions, which is helpful to perfect the lubrication analysis theory of engine bearing and can provide more comprehensive reference base for the design of connecting-rod and main bearing.

In this paper, a four-stroke four-cylinder engine is taken as the studying object, the loads and lubrication characteristics of its connecting-rod bearing and all main bearings in different engine operating conditions are calculated, and the effects of engine operating condition on the lubrication performances of connecting-rod and main bearings are researched. The parameters of the engine and its bearings are shown in Table 1.

\section{Calculation of the Loads of Bearing in Different Engine Operating Conditions}

The load of connecting-rod bearing is calculated by the dynamic calculation method [31], which is obtained by analyzing the applied forces on the engine crank-rod mechanism based on the engine cylinder pressure indicator diagram (some shown in Figure 1) measured in engine bench test and configuration parameters. The loads of all main bearings are calculated by the finite element method of whole crankshaft beam-element [31].
Table 1 Parameters of engine and bearings

\begin{tabular}{ll}
\hline Parameter & Value \\
\hline Cylinder diameter $D(\mathrm{~mm})$ & 105 \\
Stroke $S(\mathrm{~mm})$ & 118 \\
Rated power $P e(\mathrm{~kW})$ & 76 \\
Rated speed $n(\mathrm{r} / \mathrm{min})$ & 3200 \\
Width of connecting-rod bearing $L_{1}(\mathrm{~mm})$ & 30 \\
Diameter of connecting-rod bearing $D_{1}(\mathrm{~mm})$ & 66 \\
Clearance of connecting-rod bearing $C_{1}(\mathrm{~mm})$ & 0.152 \\
Width of main bearing $L_{z}(\mathrm{~mm})$ & 27 \\
Diameter of main bearing $D_{z}(\mathrm{~mm})$ & 80 \\
Clearance of main bearing $C_{z}(\mathrm{~mm})$ & 0.146 \\
Dynamic viscosity of lubricating oil $\eta(\mathrm{Pa} \cdot \mathrm{s})$ & 0.014347 \\
Oil inlet pressure $p_{0}(\mathrm{~Pa})$ & 2000 \\
\hline
\end{tabular}

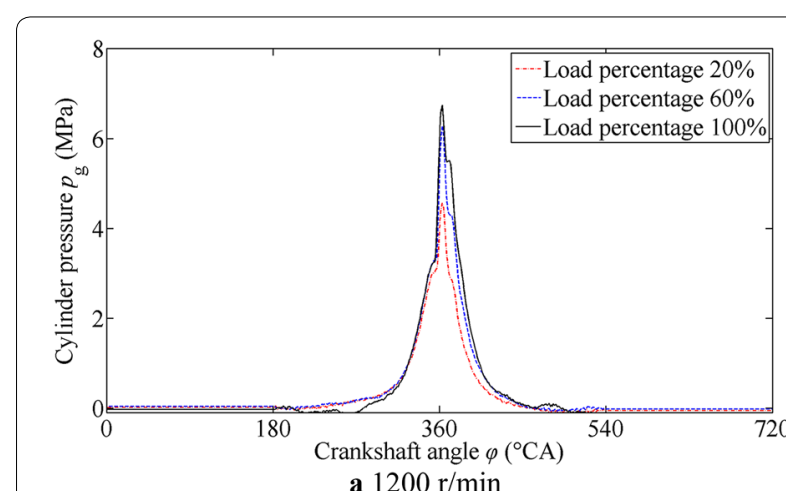

a $1200 \mathrm{r} / \mathrm{min}$
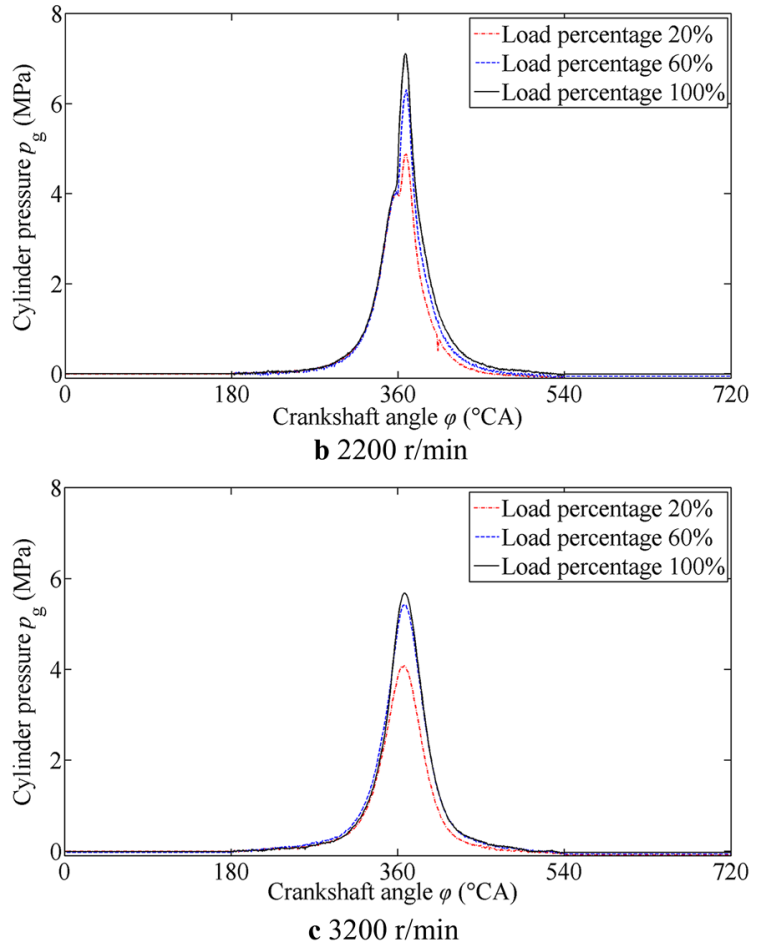

Figure 1 Indicator diagram 


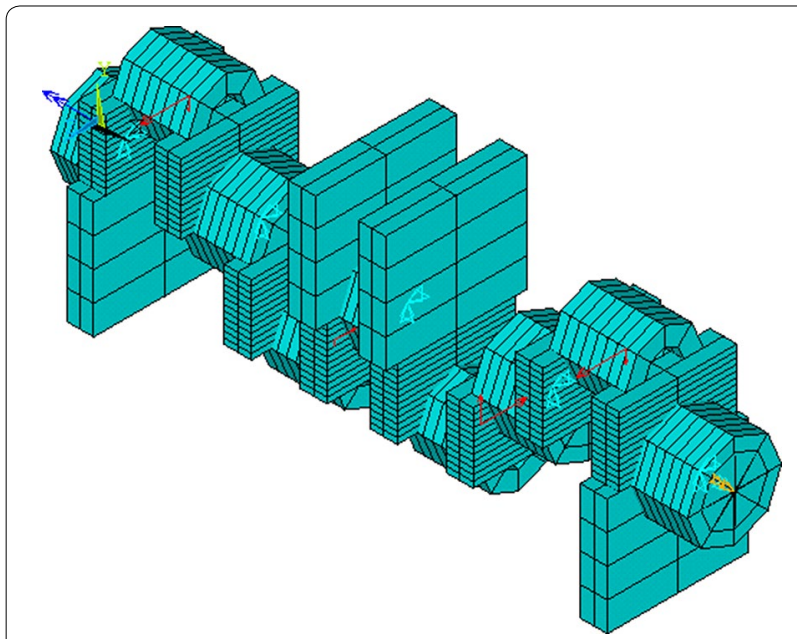

Figure 2 Beam-element finite element model of whole crankshaft

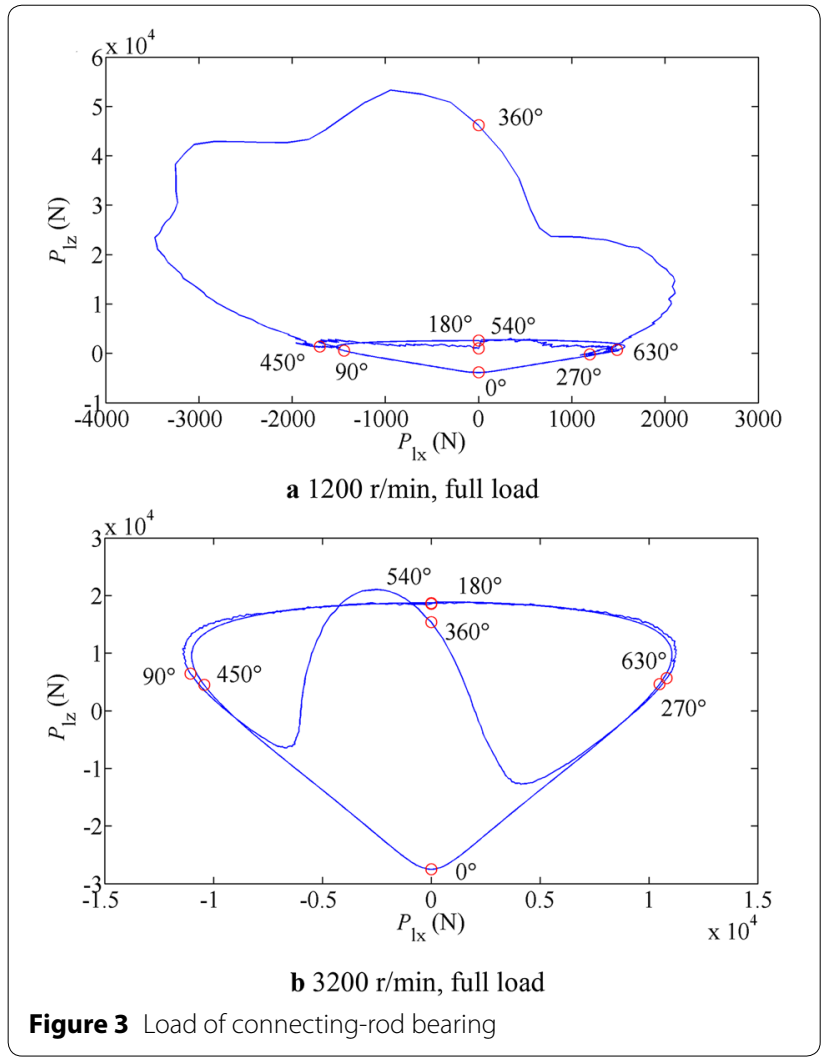

The beam-element finite element model of whole crankshaft is shown in Figure 2.

The loads of connecting-rod bearing and No. 2 main bearing under full engine load at $1200 \mathrm{r} / \mathrm{min}$ and $3200 \mathrm{r} /$ min are shown in Figures 3 and 4, respectively. There are great differences of the change rule and numerical value

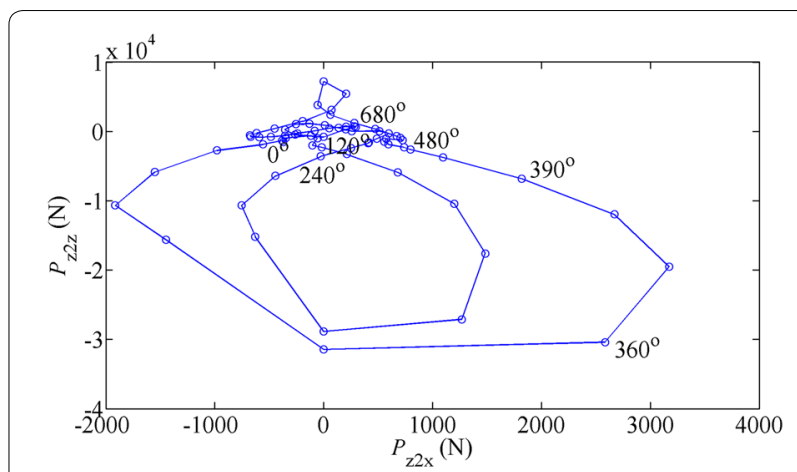

a $1200 \mathrm{r} / \mathrm{min}$, full load

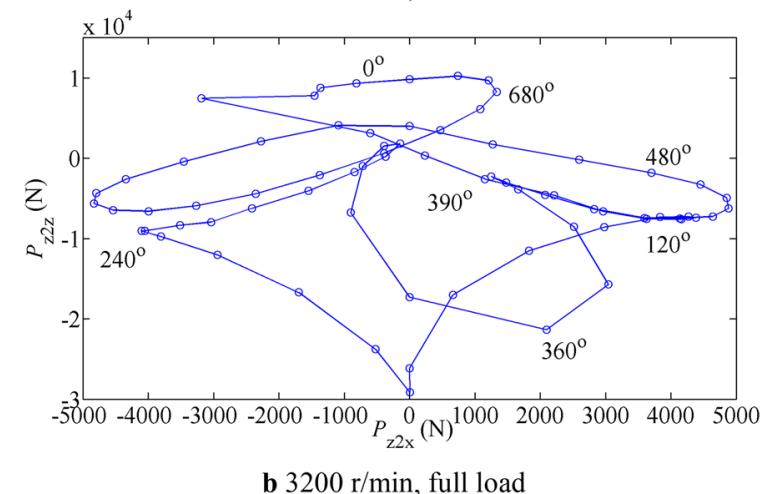

Figure 4 Load of No. 2 main bearing

of bearing load at corresponding moment in an engine operating cycle in different engine operating conditions.

The maximum loads of connecting-rod bearing and all main bearings in an engine operating cycle under full engine load at 1200, 1600, 1800, 2000, 2200, 2400, 2800 and $3200 \mathrm{r} / \mathrm{min}$ are shown in Table 2 . The maximum load of connecting-rod bearing in an engine operating cycle reduces with the increase of engine speed under same engine load.

The maximum value of the maximum load of connecting-rod bearing in an engine operating cycle appears at low engine speed $(1200 \mathrm{r} / \mathrm{min})$, and the numerical value of the maximum load of connecting-rod bearing in an engine operating cycle at high engine speed $(3200 \mathrm{r} / \mathrm{min}$, rated engine operating condition) is small. The main reason is that the load of connecting-rod bearing is decided by the actual condition of the movement and applied force of engine crank-rod mechanism. The maximum load of connecting-rod bearing in an engine operating cycle appears near to the combustion top dead center. Based on the applied force analysis of engine crank-rod mechanism, the load of connecting-rod bearing is the resultant force of the forces resulted from the cylinder pressure, the reciprocating inertial force and the rotational inertial force. The reciprocating inertial force and the rotational inertial force will be increased with the 
Table 2 Maximum loads of connecting-rod bearing and all main bearings at full load and different speed

\begin{tabular}{lllllll}
\hline Speed $(\mathbf{r} / \mathbf{m i n})$ & $\begin{array}{l}\text { Connecting-rod } \\
\text { bearing (N) }\end{array}$ & $\begin{array}{l}\text { No. 1 main } \\
\text { bearing (N) }\end{array}$ & $\begin{array}{l}\text { No. 2 main } \\
\text { bearing (N) }\end{array}$ & $\begin{array}{l}\text { No. 3 main } \\
\text { bearing (N) }\end{array}$ & $\begin{array}{l}\text { No. } 4 \text { main } \\
\text { bearing (N) }\end{array}$ & $\begin{array}{l}\text { No. } 5 \text { main } \\
\text { bearing (N) }\end{array}$ \\
\hline 1200 & 53331 & 20274 & 31468 & 25552 & 33835 & 18590 \\
1600 & 51170 & 17201 & 28939 & 18793 & 30635 & 15926 \\
1800 & 50427 & 19345 & 33061 & 20407 & 34978 & 17910 \\
2000 & 46949 & 19203 & 33030 & 18699 & 34949 & 17772 \\
2200 & 47620 & 19815 & 34587 & 17938 & 36581 & 18336 \\
2400 & 47059 & 19605 & 35388 & 15776 & 36803 & 131 \\
2800 & 37376 & 15911 & 34085 & 24240 & 34355 & 14690 \\
3200 & 27491 & 11903 & 29118 & 26126 & 29529 & 10882 \\
\hline
\end{tabular}

Table 3 Maximum loads of connecting-rod bearing and all main bearings at $2200 \mathrm{r} / \mathrm{min}$ and different load percentage

\begin{tabular}{|c|c|c|c|c|c|c|}
\hline $\begin{array}{l}\text { Load percentage } \\
\text { (\%) }\end{array}$ & $\begin{array}{l}\text { Connecting-rod } \\
\text { bearing }(\mathrm{N})\end{array}$ & $\begin{array}{l}\text { No. } 1 \text { main bearing } \\
\text { (N) }\end{array}$ & $\begin{array}{l}\text { No. } 2 \text { main bearing } \\
\text { (N) }\end{array}$ & $\begin{array}{l}\text { No. } 3 \text { main bearing } \\
\text { (N) }\end{array}$ & $\begin{array}{l}\text { No. } 4 \text { main bearing } \\
\text { (N) }\end{array}$ & $\begin{array}{l}\text { No. } 5 \text { main } \\
\text { bearing }(N)\end{array}$ \\
\hline 20 & 28691 & 12184 & 23992 & 11477 & 24135 & 11259 \\
\hline 40 & 29087 & 12720 & 23306 & 16483 & 24858 & 11757 \\
\hline 60 & 40858 & 17392 & 30918 & 14547 & 32491 & 16089 \\
\hline 80 & 44273 & 18675 & 32765 & 16334 & 34650 & 17277 \\
\hline 100 & 47620 & 19815 & 34587 & 17938 & 36581 & 18336 \\
\hline
\end{tabular}

increase of engine speed, but the acting directions of the reciprocating inertial force and the rotational inertial force at the combustion top dead center are opposite to the direction of force resulted from the cylinder pressure, so the higher the engine speed the more the reduction of the maximum load of connecting-rod bearing. The change situation of the maximum load of one main bearing in an engine operating cycle against the engine speed is different from that of another main bearing under same engine load. The loads of No. 1 and No. 5 main bearing are affected mainly by the force on single crank, and the maximum loads of No. 1 and No. 5 main bearing happen at the lower engine speed $(1200 \mathrm{r} / \mathrm{min})$. The loads of No. 2, No. 3 and No. 4 main bearing are decided by the forces of adjacent two cranks, and the maximum loads of No. 2, No. 3 and No. 4 main bearing happen at the higher engine speed.

The maximum loads of connecting-rod bearing and all main bearings in an engine operating cycle at $2200 \mathrm{r} / \mathrm{min}$ under $20 \%, 40 \%, 60 \%, 80 \%$ and full engine load are shown in Table 3. Under the same engine speed, the maximum loads of connecting-rod bearing and all main bearings in an engine operating cycle increase basically with the increase of engine load, and the maximum loads of connecting-rod bearing and all main bearings in an engine operating cycle take place at full engine load.

\section{Lubrication Analysis of Connecting-Rod and Main Bearing in Different Engine Operating Condition}

\subsection{Method and Formulation}

The journal axis orbits of all bearings are calculated by the dynamic method in the lubrication analyses of all connecting-rod or main bearings [32].

\subsubsection{Reynolds' Equation [33]}

$$
\frac{\partial}{\partial \theta}\left(h^{3} \frac{\partial p}{\partial \theta}\right)+R_{\mathrm{b}}^{2} \frac{\partial}{\partial y}\left(h^{3} \frac{\partial p}{\partial y}\right)=6 \eta R_{\mathrm{b}}\left(u \frac{\partial h}{\partial \theta}+2 R_{\mathrm{b}} \frac{\partial h}{\partial t}\right)
$$

where $p$ is the oil film pressure, $h$ is the oil film thickness, $\eta$ is dynamic viscosity of lubricating oil, $u=u_{\mathrm{j}}+u_{\mathrm{b}}, u_{\mathrm{j}}$ is the velocity of journal surface and $u_{\mathrm{j}}=R_{\mathrm{j}} \omega_{\mathrm{j}}, R_{\mathrm{j}}$ is the journal radius, $\omega_{\mathrm{j}}$ is the angular velocity of journal, $u_{\mathrm{b}}$ is the velocity of bearing surface and $u_{\mathrm{b}}=R_{\mathrm{b}} \omega_{\mathrm{b}}, R_{\mathrm{b}}$ is the bearing radius, $\omega_{\mathrm{b}}$ is the angular velocity of bearing.

Reynolds' equation is solved by the finite difference method.

\subsubsection{Oil Film Thickness [34]}

$$
h=c+e \cos (\theta-\psi)+\delta,
$$




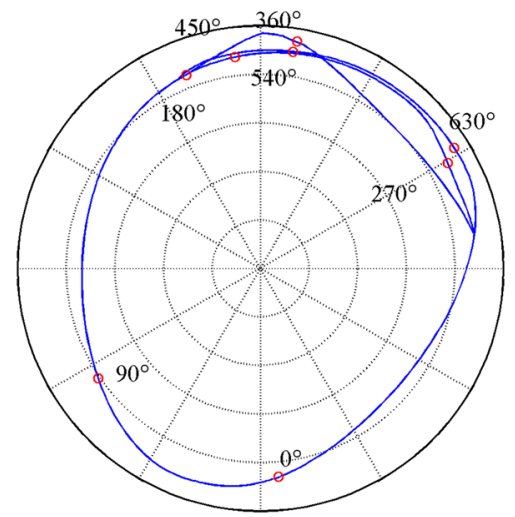

a $1200 \mathrm{r} / \mathrm{min}$, full load

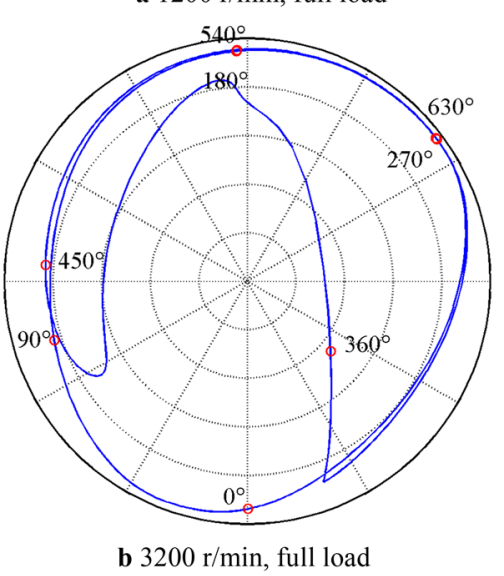

Figure 5 Journal axis orbit of connecting-rod bearing

where $c$ is the radial clearance of bearing, $e$ is the journal eccentric distance of bearing, $\psi$ is the attitude angle of bearing, $\delta$ is the change of oil film thickness caused by elastic deformation of bush surface of bearing under oil film pressure, and the elastic deformation of bush surface of bearing under oil film pressure is calculated by the compliance matrix method.

\subsubsection{Load Equilibrium Equation}

If the effect of the oil film inertia is not considered, the motion of the journal axes of bearing conforms to the Newton second law, that is,

$$
\boldsymbol{P}+\boldsymbol{F}=m_{\mathrm{j}} \frac{\mathrm{d} \boldsymbol{v}}{\mathrm{d} t},
$$

where $\boldsymbol{P}$ is the load vector of bearing, $\boldsymbol{F}$ is the resultant oil film force vector of bearing, $v$ is the velocity vector of journal axes.

\subsubsection{End Leakage Flow-Rate of Bearing}

The lubricating oil flow-rate $Q_{1}$ from the front-end plane of bearing and the lubricating oil flow-rate $Q_{2}$ from the rear-end plane of bearing are given by

$$
\begin{aligned}
& Q_{1}=-\left.\int_{0}^{2 \pi} \frac{h^{3}}{12 \eta} \cdot \frac{\partial p}{\partial y}\right|_{y=0} \cdot R_{\mathrm{b}} \mathrm{d} \theta \\
& Q_{2}=-\left.\int_{0}^{2 \pi} \frac{h^{3}}{12 \eta} \cdot \frac{\partial p}{\partial y}\right|_{y=L} \cdot R_{\mathrm{b}} \mathrm{d} \theta .
\end{aligned}
$$

The total end leakage flow-rate $Q$ of the lubricating oil is then given by

$$
Q=\left|Q_{1}\right|+\left|Q_{2}\right| .
$$

\subsubsection{Frictional Coefficient and Average Frictional Power Loss of Bearing}

The frictional force on the journal surface $F_{\mathrm{j}}$ can be calculated from

$$
F_{\mathrm{j}}=\int_{0}^{L} \int_{0}^{2 \pi}\left(\frac{h}{2} \frac{\partial p}{R_{\mathrm{j}} \partial \theta}+\frac{u \eta}{h}\right) R_{\mathrm{j}} \mathrm{d} \theta \mathrm{d} y .
$$

The frictional coefficient of the journal surface $\mu_{\mathrm{j}}$ is then given by

$$
\mu_{\mathrm{j}}=\frac{F_{\mathrm{j}}}{F} .
$$

The average frictional power loss of bearing in an engine operating cycle is then given by

$$
w_{\mathrm{m}}=\sum_{i=1}^{720}\left(F_{\mathrm{j}}\right)_{i} u / 720 .
$$

\subsection{Results and Discussion}

The journal axes orbits, maximum oil film pressures, minimum oil film thicknesses, end leakage flow-rates and frictional coefficients of connecting-rod bearing and No. 2 main bearing in an engine operating cycle under full engine load at $1200 \mathrm{r} / \mathrm{min}$ and $3200 \mathrm{r} / \mathrm{min}$ are shown in Figures 5, 6, 7, 8, 9, 10, 11, 12, 13, 14. In different engine operating conditions, there are major differences of the lubrication performance of bearings, and there are obvious differences in the changes and numerical values of the journal axes orbits, maximum oil film pressures, minimum oil film thicknesses, end leakage flow-rates and frictional coefficients of bearings in an engine operating cycle.

The maximum oil film pressures, minimum oil film thicknesses and average frictional power losses of connecting-rod bearing and all main bearings in an engine 


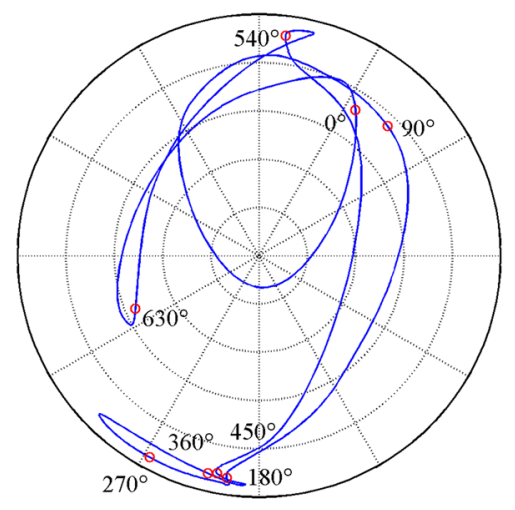

a $1200 \mathrm{r} / \mathrm{min}$, full load

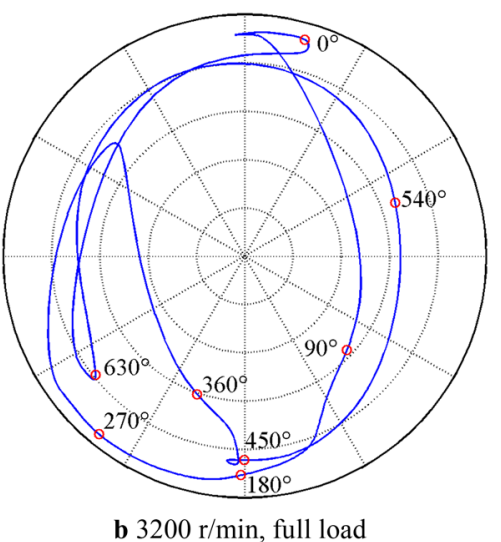

Figure 6 Journal axis orbit of No. 2 main bearing

operating cycle under full engine load and at 1200, 1600, $1800,2000,2200,2400,2800$ and $3200 \mathrm{r} / \mathrm{min}$ respectively are shown in Tables 4, 5, 6 .

When the engine load is same, the maximum oil film pressure of connecting-rod bearing in an engine operating cycle is decreased generally with the increase of engine speed, and the maximum oil film pressure (372.52 MPa) of connecting-rod bearing at $1200 \mathrm{r} / \mathrm{min}$ is as 4.02 times as that $(92.74 \mathrm{MPa})$ at $3200 \mathrm{r} / \mathrm{min}$, which shows that the maximum oil film pressure of connecting-rod bearing at lower engine speed is larger remarkably than the one at higher engine speed under the same engine load. The main reason why the maximum oil film pressure of connecting-rod bearing at lower engine speed is larger than the one at higher engine speed under the same engine load is that, when the engine load is same, the maximum load of connecting-rod is decreased basically with the increase of engine speed, and the maximum load of connecting-rod at $1200 \mathrm{r} / \mathrm{min}$ is larger remarkably than the one at $3200 \mathrm{r} / \mathrm{min}$.

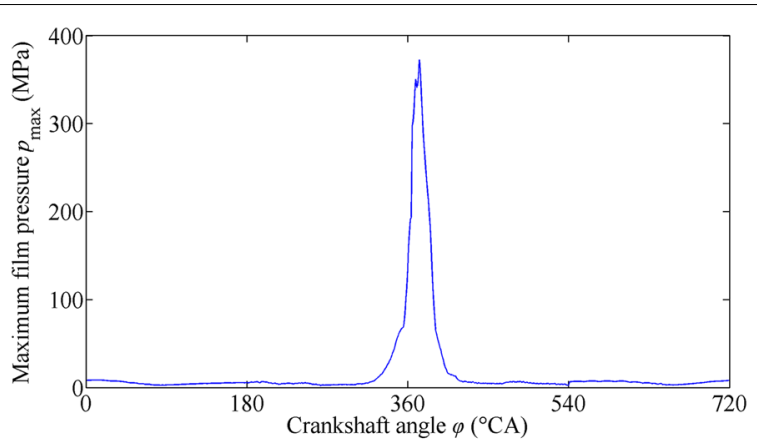

a $1200 \mathrm{r} / \mathrm{min}$, full load

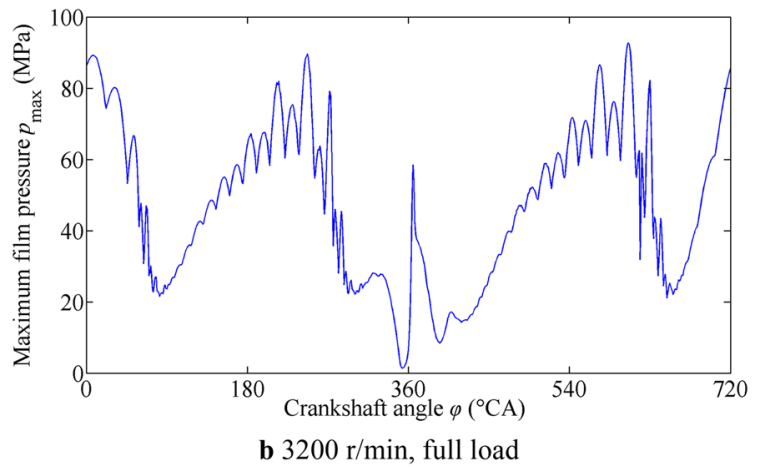

Figure 7 Maximum oil film pressure of connecting-rod bearing

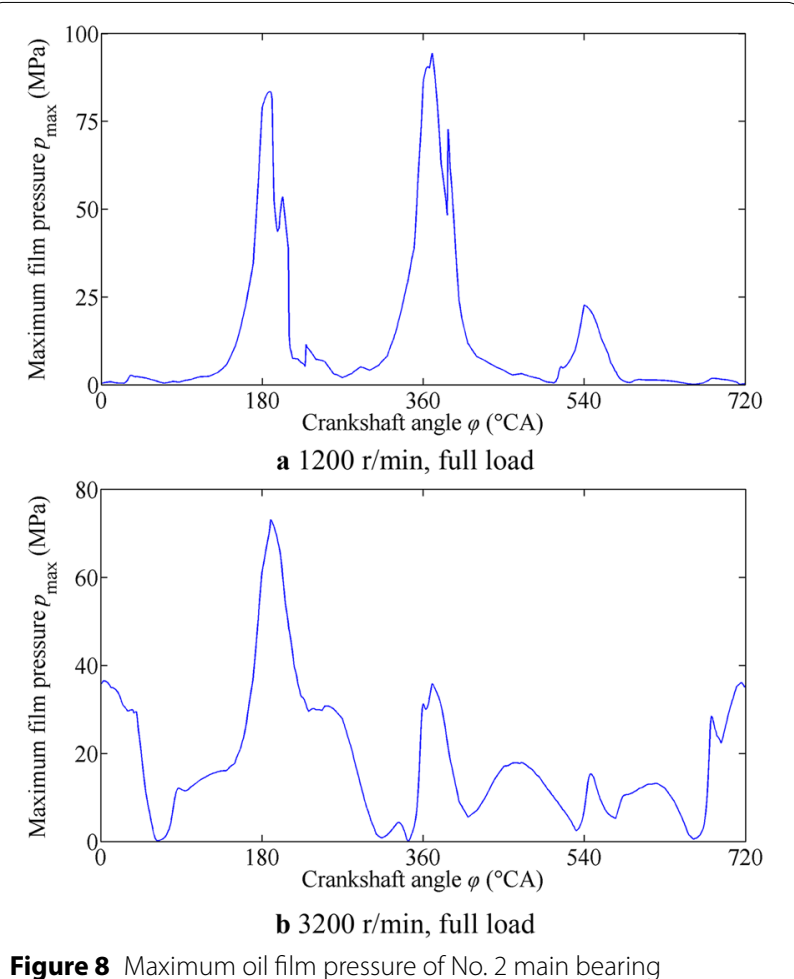

Figure 8 Maximum oil film pressure of No. 2 main bearing 

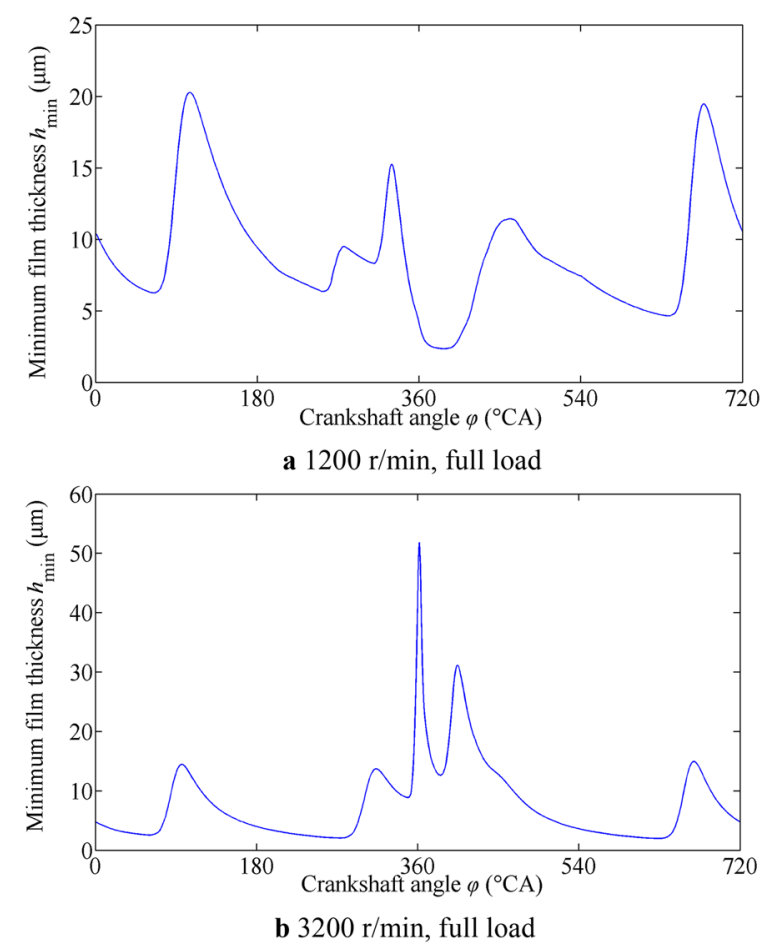

Figure 9 Minimum oil film thickness of connecting-rod bearing
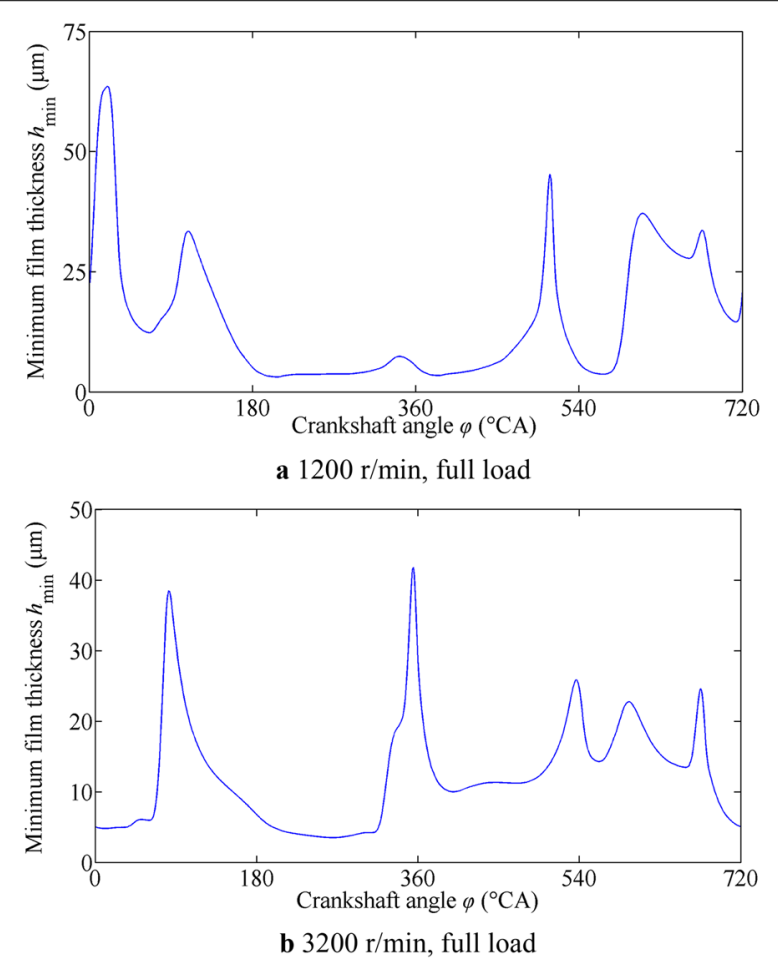

Figure 10 Minimum oil film thickness of No. 2 main bearing

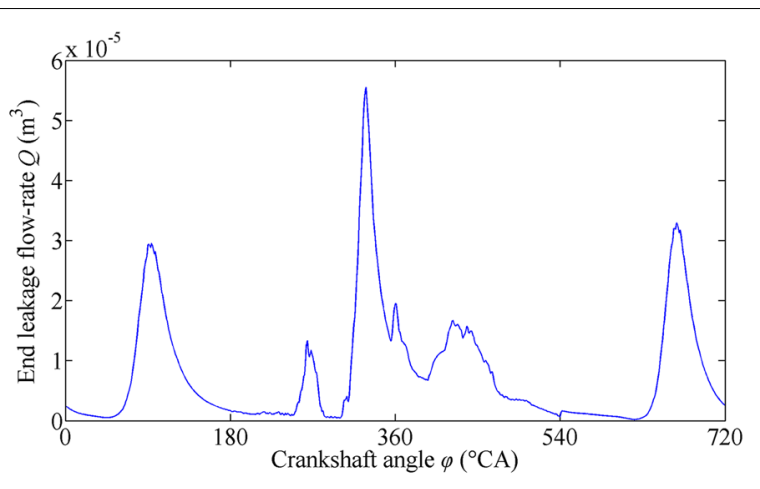

a $1200 \mathrm{r} / \mathrm{min}$, full load

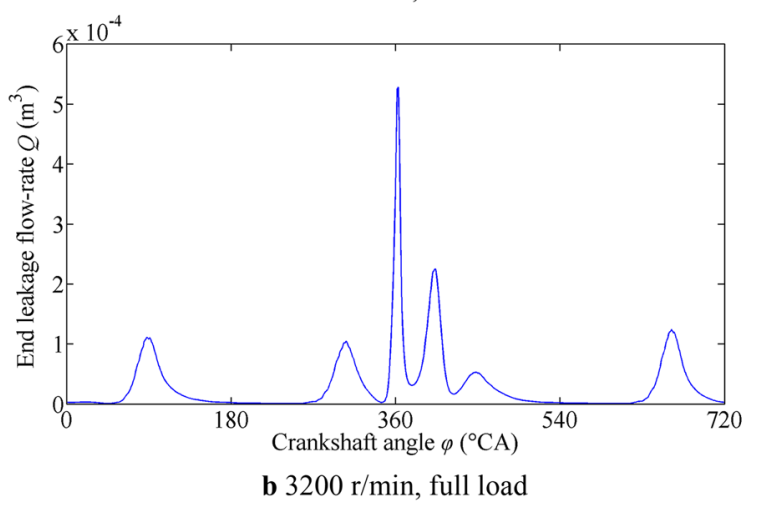

Figure 11 End leakage flow-rate of connecting-rod bearing

When the engine load is same, the changes of the maximum oil film pressures of all main bearings in an engine operating cycle is different one another with the change of engine speed. The maximum oil film pressures of No. 1 and No. 5 main bearings do not have obvious change at different engine speed, the maximum oil film pressures of No. 2 and No. 4 main bearings are larger at lower engine speed, and the maximum oil film pressure of No. 3 main bearings is larger at higher engine speed.

When the engine load is same, the minimum oil film thicknesses of connecting-rod bearing and all main bearings in an engine operating cycle do not have the same change one another with the change of engine speed. The minimum oil film thicknesses of connecting-rod bearing and all main bearings in an engine operating cycle at higher engine speed $(3200 \mathrm{r} / \mathrm{min}$ ) are generally smaller in addition to the individual circumstances.

When the engine load is same, the average frictional power losses of connecting-rod bearing and all main bearings increase with the increase of engine speed, and the average frictional power losses of connecting-rod bearing and all main bearings are the largest at higher engine speed ( $3200 \mathrm{r} / \mathrm{min}$ ).

The maximum oil film pressures, minimum oil film thicknesses and average frictional power losses of 

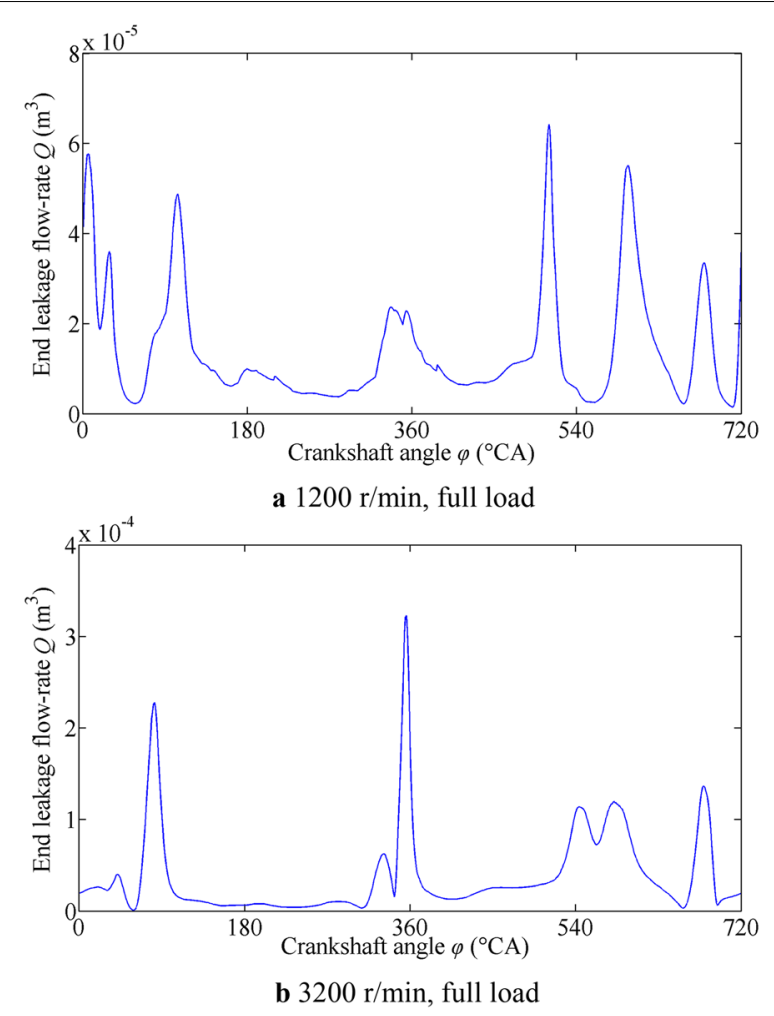

Figure 12 End leakage flow-rate of No. 2 main bearing
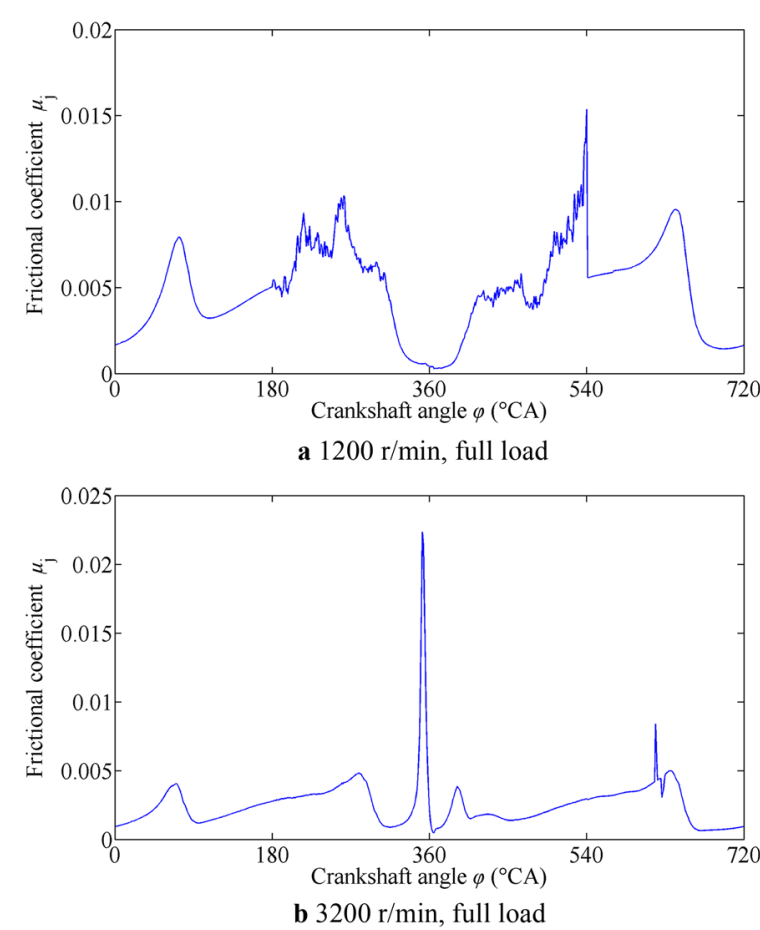

Figure 13 Frictional coefficient of connecting-rod bearing

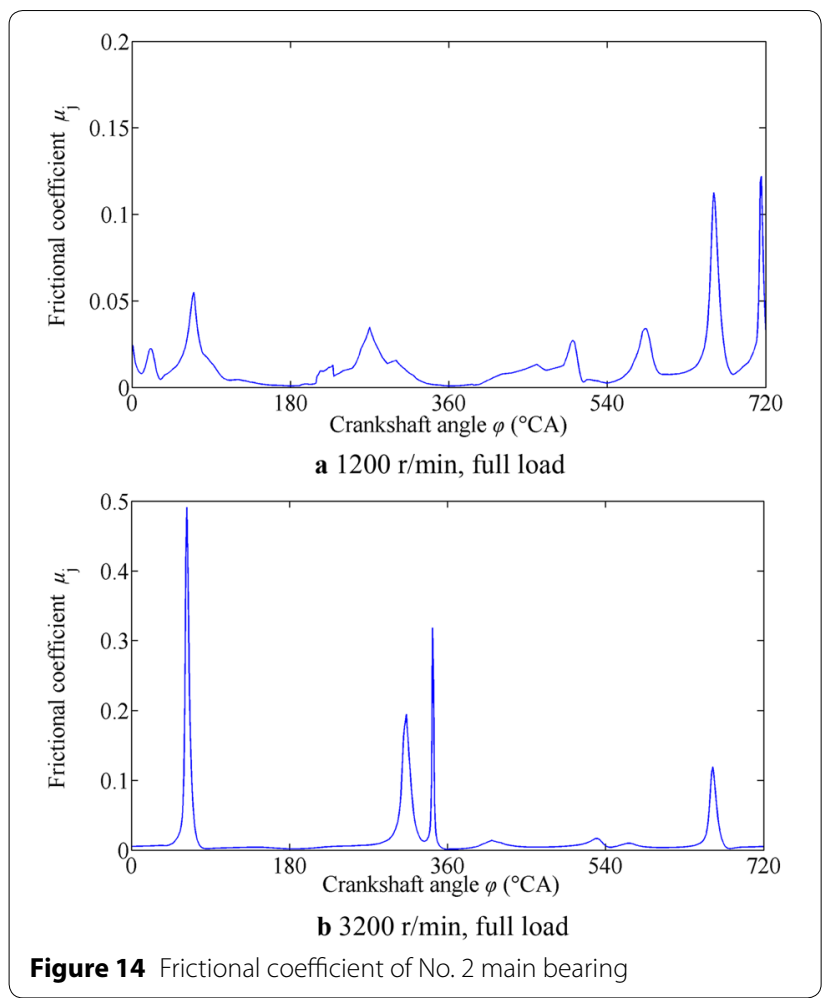

connecting-rod bearing and all main bearings in an engine operating cycle at $2200 \mathrm{r} / \mathrm{min}$ under $20 \%, 40 \%$, $60 \%, 80 \%$ and full engine load are shown in Tables 7, 8, 9.

When the engine speed is same, the maximum oil film pressures of connecting-rod bearing and all main bearings in an engine operating cycle are increased generally with the increase of engine load, but the maximum value of the maximum oil film pressures of No. 3 main bearing is appeared at the smaller engine load (40\%).

When the engine speed is same, the minimum oil film thickness of connecting-rod bearing is decreased with the increase of engine load, and the maximum value appears at the full engine load (100\%). The minimum oil film thicknesses of all main bearings do not have the same change with the change of engine load, the minimum values of the minimum oil film thicknesses of Nos. 1, 4, 5 main bearings all appear at the full engine load $(100 \%)$, and the minimum values of the minimum oil film thicknesses of Nos. 2, 3 main bearings appear at the smaller engine load.

When the engine speed is same, the average frictional power losses of connecting-rod bearing and all main bearings in an engine operating cycle do not change obviously with the change of engine load. The average frictional power losses of connecting-rod bearing and all main bearings in an engine operating cycle are generally 
Table 4 Maximum film pressures of connecting-rod bearing and main bearings at full load and different speed

\begin{tabular}{lllllll}
\hline Speed $(\mathbf{r} / \mathbf{m i n})$ & $\begin{array}{l}\text { Connecting-rod } \\
\text { bearing (MPa) }\end{array}$ & $\begin{array}{l}\text { No. 1 main } \\
\text { bearing (MPa) }\end{array}$ & $\begin{array}{l}\text { No. 2 main } \\
\text { bearing (MPa) }\end{array}$ & $\begin{array}{l}\text { No. 3 main } \\
\text { bearing (MPa) }\end{array}$ & $\begin{array}{l}\text { No. } 4 \text { main } \\
\text { bearing (MPa) }\end{array}$ & $\begin{array}{l}\text { No. 5 main } \\
\text { bearing } \\
\text { (MPa) }\end{array}$ \\
\hline 1200 & 372.52 & 47.70 & 94.41 & 88.91 & 143.88 & 43.51 \\
1600 & 221.53 & 37.71 & 109.10 & 38.33 & 147.12 & 34.24 \\
1800 & 153.78 & 38.55 & 87.20 & 36.47 & 91.72 & 35.28 \\
2000 & 136.71 & 37.00 & 92.38 & 30.46 & 91.92 & 32.29 \\
2200 & 129.58 & 36.04 & 94.06 & 33.27 & 95.51 & 32.75 \\
2400 & 120.20 & 34.70 & 97.56 & 43.17 & 98.58 & 31.49 \\
2800 & 136.22 & 39.39 & 75.86 & 115.56 & 71.16 & 38.46 \\
3200 & 92.74 & 50.10 & 73.14 & 115.79 & 73.07 & 45.26 \\
\hline
\end{tabular}

Table 5 Minimum film thicknesses of connecting-rod bearing and main bearings at full load and different speed

\begin{tabular}{|c|c|c|c|c|c|c|}
\hline Speed (r/min) & $\begin{array}{l}\text { Connecting-rod } \\
\text { bearing }(\mu \mathrm{m})\end{array}$ & $\begin{array}{l}\text { No. } 1 \text { main } \\
\text { bearing }(\mu \mathrm{m})\end{array}$ & $\begin{array}{l}\text { No. } 2 \text { main } \\
\text { bearing }(\mu \mathrm{m})\end{array}$ & $\begin{array}{l}\text { No. } 3 \text { main } \\
\text { bearing }(\mu \mathrm{m})\end{array}$ & $\begin{array}{l}\text { No. } 4 \text { main } \\
\text { bearing }(\mu \mathrm{m})\end{array}$ & $\begin{array}{l}\text { No. } 5 \text { main } \\
\text { bearing }(\mu \mathrm{m})\end{array}$ \\
\hline 1200 & 2.34 & 4.35 & 3.08 & 4.31 & 3.01 & 5.04 \\
\hline 1600 & 3.05 & 3.63 & 3.51 & 5.08 & 3.27 & 3.84 \\
\hline 1800 & 3.13 & 3.23 & 3.38 & 4.30 & 3.20 & 3.39 \\
\hline 2000 & 2.65 & 3.20 & 3.39 & 4.11 & 3.16 & 3.56 \\
\hline 2200 & 2.58 & 2.96 & 3.34 & 3.47 & 3.08 & 3.39 \\
\hline 2400 & 2.39 & 2.81 & 3.30 & 3.07 & 3.06 & 3.33 \\
\hline 2800 & 2.48 & 2.56 & 4.48 & 1.83 & 3.31 & 3.61 \\
\hline 3200 & 1.97 & 2.09 & 3.12 & 1.42 & 3.01 & 2.90 \\
\hline
\end{tabular}

increased slightly with the increase of engine load in addition to the individual engine loads.

In addition, the corresponding comparisons between the lubrication performance of connecting-rod bearing and the one of main bearings at same engine operating condition (shown in Tables 4, 5, 6, 7, 8, 9) show that, the maximum oil film pressure of connecting-rod bearing in an engine operating cycle is larger than those of all main bearings, the minimum oil film thickness of connectingrod bearing in an engine operating cycle is smaller than those of all main bearings, and the average frictional power losses of connecting-rod bearing in an engine operating cycle is smaller than those of all main bearings. Also, there is the corresponding difference between the lubrication performances (the maximum oil film pressure, minimum oil film thickness and average frictional power loss in an engine operating cycle) of all main bearings one another at same engine operating condition, and some difference is larger.

\section{Conclusions}

(1) In different engine operating conditions, there are great differences of the loads of connecting-rod and main bearings. When the engine load is same, the maximum load of connecting-rod bearing appears at the lower engine speed, the maximum loads of some main bearings appear at the lower engine speed but the others appear at the higher engine speed. When the engine speed is same, the maximum loads of connecting-rod bearing and all main bearings appear at the full engine load.

(2) In different engine operating conditions, there are obvious difference of the lubrication performance of connecting-rod and main bearing.

When the engine load is same, the maximum oil film pressure of connecting-rod bearing at lower engine speed is larger obviously than the one at higher engine speed; the change of the maximum oil film pressure of each main bearing with the engine speed is not the same; the smaller values of the minimum oil film thicknesses of connectingrod bearing and all main bearings appear generally at higher engine speed; the maximum average fric- 
Table 6 Average friction power losses of connecting-rod bearing and main bearings at full load and different speed

\begin{tabular}{|c|c|c|c|c|c|c|}
\hline Speed ( $r / \mathrm{min})$ & $\begin{array}{l}\text { Connecting-rod } \\
\text { bearing (W) }\end{array}$ & $\begin{array}{l}\text { No. } 1 \text { main } \\
\text { bearing }(W)\end{array}$ & $\begin{array}{l}\text { No. } 2 \text { main } \\
\text { bearing }(W)\end{array}$ & $\begin{array}{l}\text { No. } 3 \text { main } \\
\text { bearing }(W)\end{array}$ & $\begin{array}{l}\text { No. } 4 \text { main } \\
\text { bearing (W) }\end{array}$ & $\begin{array}{l}\text { No. } 5 \text { main } \\
\text { bearing }(W)\end{array}$ \\
\hline 1200 & 43.74 & 56.53 & 49.53 & 55.55 & 50.73 & 57.45 \\
\hline 1600 & 83.55 & 98.02 & 95.14 & 114.62 & 98.54 & 97.20 \\
\hline 1800 & 102.09 & 118.07 & 124.11 & 145.81 & 129.42 & 117.84 \\
\hline 2000 & 132.33 & 161.82 & 144.88 & 180.93 & 155.34 & 153.26 \\
\hline 2200 & 150.77 & 201.86 & 189.04 & 218.17 & 201.40 & 185.02 \\
\hline 2400 & 177.09 & 242.79 & 226.87 & 255.20 & 244.85 & 216.11 \\
\hline 2800 & 245.28 & 293.11 & 252.78 & 463.87 & 290.62 & 248.65 \\
\hline 3200 & 271.30 & 413.43 & 392.23 & 515.31 & 442.73 & 382.44 \\
\hline
\end{tabular}

Table 7 Maximum film pressures of connecting-rod bearing and main bearings at $2200 \mathrm{r} / \mathrm{min}$ and different load percentage

\begin{tabular}{|c|c|c|c|c|c|c|}
\hline $\begin{array}{l}\text { Load percentage } \\
\text { (\%) }\end{array}$ & $\begin{array}{l}\text { Connecting-rod } \\
\text { bearing ( } \mathrm{MPa} \text { ) }\end{array}$ & $\begin{array}{l}\text { No. } 1 \text { main bearing } \\
\text { (MPa) }\end{array}$ & $\begin{array}{l}\text { No. } 2 \text { main bearing } \\
(\mathrm{MPa})\end{array}$ & $\begin{array}{l}\text { No. } 3 \text { main bearing } \\
(\mathrm{MPa})\end{array}$ & $\begin{array}{l}\text { No. } 4 \text { main bearing } \\
\text { (MPa) }\end{array}$ & $\begin{array}{l}\text { No. } 5 \text { main } \\
\text { bearing } \\
(\mathrm{MPa})\end{array}$ \\
\hline 20 & 70.48 & 21.19 & 37.00 & 37.84 & 62.98 & 19.00 \\
\hline 40 & 68.20 & 21.21 & 58.90 & 45.69 & 64.49 & 19.00 \\
\hline 60 & 106.24 & 30.36 & 83.19 & 33.71 & 84.43 & 27.59 \\
\hline 80 & 118.66 & 33.35 & 89.35 & 32.96 & 90.63 & 30.32 \\
\hline 100 & 129.58 & 36.04 & 94.06 & 33.27 & 95.51 & 32.75 \\
\hline
\end{tabular}

Table 8 Minimum film thicknesses of connecting-rod bearing and main bearings at $2200 \mathrm{r} / \mathrm{min}$ and different load percentage

\begin{tabular}{|c|c|c|c|c|c|c|}
\hline $\begin{array}{l}\text { Load percentage } \\
\text { (\%) }\end{array}$ & $\begin{array}{l}\text { Connecting-rod } \\
\text { bearing }(\mu \mathrm{m})\end{array}$ & $\begin{array}{l}\text { No. } 1 \text { main bearing } \\
(\mu \mathrm{m})\end{array}$ & $\begin{array}{l}\text { No. } 2 \text { main bearing } \\
(\mu \mathrm{m})\end{array}$ & $\begin{array}{l}\text { No. } 3 \text { main bearing } \\
(\mu \mathrm{m})\end{array}$ & $\begin{array}{l}\text { No. } 4 \text { main bearing } \\
(\mu \mathrm{m})\end{array}$ & $\begin{array}{l}\text { No. } 5 \text { main } \\
\text { bearing }(\mu \mathrm{m})\end{array}$ \\
\hline 20 & 2.96 & 2.97 & 3.20 & 3.48 & 3.68 & 3.63 \\
\hline 40 & 2.92 & 2.98 & 3.82 & 3.24 & 3.64 & 3.65 \\
\hline 60 & 2.79 & 2.97 & 3.46 & 3.42 & 3.26 & 3.45 \\
\hline 80 & 2.70 & 2.97 & 3.40 & 3.49 & 3.18 & 3.60 \\
\hline 100 & 2.58 & 2.96 & 3.34 & 3.47 & 3.08 & 3.39 \\
\hline
\end{tabular}

Table 9 Average friction power losses of connecting-rod bearing and main bearings at $2200 \mathrm{r} / \mathrm{min}$ and different load percentage

\begin{tabular}{|c|c|c|c|c|c|c|}
\hline $\begin{array}{l}\text { Load percentage } \\
\text { (\%) }\end{array}$ & $\begin{array}{l}\text { Connecting-rod } \\
\text { bearing }(W)\end{array}$ & $\begin{array}{l}\text { No. } 1 \text { main bearing } \\
\text { (W) }\end{array}$ & $\begin{array}{l}\text { No. } 2 \text { main bearing } \\
\text { (W) }\end{array}$ & $\begin{array}{l}\text { No. } 3 \text { main bearing } \\
\text { (W) }\end{array}$ & $\begin{array}{l}\text { No. } 4 \text { main bearing } \\
\text { (W) }\end{array}$ & $\begin{array}{l}\text { No. } 5 \text { main } \\
\text { bearing }(W)\end{array}$ \\
\hline 20 & 136.99 & 196.14 & 188.14 & 212.51 & 200.18 & 173.85 \\
\hline 40 & 134.66 & 195.25 & 188.04 & 176.99 & 188.04 & 173.10 \\
\hline 60 & 145.50 & 198.77 & 190.54 & 214.24 & 203.35 & 178.23 \\
\hline 80 & 150.90 & 201.64 & 189.76 & 216.54 & 203.03 & 179.63 \\
\hline 100 & 150.77 & 201.86 & 189.04 & 218.17 & 201.40 & 185.02 \\
\hline
\end{tabular}

tional power losses of connecting-rod bearing and all main bearings happen at higher engine speed.

When the engine speed is same, the maximum oil film pressures of connecting-rod bearing and main bearings increase generally with the increase of engine load; the minimum oil film thickness of connecting-rod bearing happens at the full engine load, the minimum oil film thicknesses of some main 
bearings happen at the full engine load but some other happen at the lower engine load; the average frictional power losses of connecting-rod bearing and all main bearings do not have evident change with the change of engine load.

(3) Under the same engine operating condition, the maximum oil film pressure of connecting-rod bearing is larger than the one of main bearing; the minimum oil film thickness of connecting-rod bearing is smaller than the one of main bearing; the average frictional power loss of connecting-rod bearing is smaller than the one of main bearing.

(4) There are the larger difference between the lubrication performances of main bearings one another under same engine operating condition.

Therefore, it is not comprehensive and reasonable that only the lubrication performance of a certain connecting-rod bearing or main bearing at rated engine operating condition is analyzed. It is necessary to analyze simultaneously the lubrication performance of connecting-rod bearing and all main bearings in different engine operating conditions in the design of engine.

\section{Authors' Contributions}

JS was in charge of the whole trial; BL wrote the manuscript; SZ and EM assisted with the lubrication analyses of bearing; HW and XZ assisted with the finite element analysis; QT assisted with the measurement of engine cylinder pressure. All authors read and approved the final manuscript.

\section{Author Details \\ ${ }^{1}$ School of Automotive and Transportation Engineering, Hefei University of Technology, Hefei 230009, China. ${ }^{2}$ School of Mechanical Engineering, Hefei University of Technology, Hefei 230009, China. ${ }^{3}$ School of Instrument Science and Opto-electronics Engineering, Hefei University of Technology, Hefei 230009, China.}

\section{Authors' Information}

Jun Sun, born in 1960, is currently a professor at School of Automotive and Transportation Engineering, Hefei University of Technology, China. He received his PhD degree from Hefei University of Technology, China, in 2005. His research interests include tribology and modern design theory and method.

Biao Li, born in 1991, is currently a PhD candidate at School of Mechanical Engineering, Hefei University of Technology, China. He received his master degree from Anhui University of Technology, China, in 2016.

Shaoyu Zhu, born in 1994, is currently a PhD candidate at School of Automotive and Transportation Engineering, Hefei University of Technology, China. He received his bachelor degree from Hefei University of Technology, China, in 2015.

Enming Miao, born in 1971, is currently a professor at School of Instrument Science and Opto-electronics Engineering, Hefei University of Technology, China. He received his PhD degree from Hefei University of Technology, China, in 2004.

Hu Wang, born in 1972, is currently a professor at School of Mechanical Engineering, Hefei University of Technology, China. He received his PhD degree from Hefei University of Technology, China, in 2010.

Xiaoyong Zhao, born in 1962, is currently a professor at School of Mechanical Engineering, Hefei University of Technology, China.
Qin Teng, born in 1962, is currently a professor at School of Automotive and Transportation Engineering, Hefei University of Technology, China. He received his PhD degree from Hefei University of Technology, China, in 2007.

\section{Competing Interests}

The authors declare that they have no competing interests.

\section{Funding}

Supported by Science Fund of State Key Laboratory of Engine Reliability of China (Grant No. skler-201708) and National Natural Science Foundation of China (Grant No. 51490660/51490661).

\section{Publisher's Note}

Springer Nature remains neutral with regard to jurisdictional claims in published maps and institutional affiliations.

Received: 7 August 2017 Accepted: 22 February 2019

Published online: 13 March 2019

\section{References}

[1] R C Liu, X H Meng, P Li. Transient tribodynamic analysis of crankshaftmain bearing system during engines starting up. Proc MechE Part J: J Engineering Tribology, 2018, 232(5): 535-549.

[2] J P Zammit, P J Shayler, R Gardiner. Investigating the potential to reduce crankshaft main bearing friction during engine warm-up by raising oil feed temperature. SAE Paper 2012-01-1216, 2012.

[3] M Inui, M Kobayashi, K Oowaki, et al. Analysis of oil film generation on the main journal bearing using a thin-film sensor and elasto-hydrodynamic lubrication(EHL) model. SAE Paper 2013-01-1217, 2013.

[4] D Jia, L Shen, Y Bi, et al. A study on the factors affecting the lubrication characteristics of connecting rod big-end bearing in diesel engine. Automotive Engineering, 2012, 34(11): 981-983.

[5] L Galera, A S Rodrigues. Optimization of lemon shape big end profile connecting rod under engine operation in elastohydrodynamic regime. SAE Paper 2014-36-0309, 2014

[6] CX Gu, X H Meng, D Zhang, et al. A transient analysis of the textured journal bearing considering micro and macro cavitation during an engine cycle. Proc IMechE Part J: J Engineering Tribology, 2017, 231 (10): 1289-1306.

[7] M Mohammadpour, R Rahmani, H Rahnejat. Effect of cylinder deactivation on the tribo-dynamics and acoustic emission of overlay big end bearings. Proc IMechE Part K: J Multi-body Dynamics, 2014, 228(2): 138-151.

[8] M Mahdi, R Ramin, R Homer. The effect of cylinder de-activation on thermo-friction characteristics of the connecting rod bearing in the new european drive cycle (NEDC). SAE Paper 2014-01-2089, 2014.

[9] X R Liu, GX Li, J Lu, et al. Simulation of diesel engine main bearing lubrication under single cylinder fuel cutoff condition. Chinese Internal Combustion Engine Engineering, 2014, 35(6): 25-30.

[10] A Francisco, T Lavie, A Fatu, et al. Metamodel-assisted optimization of connecting rod big-end bearings. Journal of Tribology, 2013, 135: 0417041-04170410.

[11] T Lavie, A Fransisco, A Fatu, et al. Multiobjective optimization of conrod big-end bearing lubrication using an evolutionary algorithm. Tribology Transactions, 2015, 58: 490-499.

[12] J H Zhang, G C Zhang, Z P He, et al. Optimization of crankshaft-bearing lubricating characteristics based on orthogonal experiment and neural network. Transactions of CSICE, 2011, 29(5): 461-467.

[13] T Ozasa, K Maitani, Y Fujimoto, et al. Simplified estimation method of bearing friction for engines. International J. of Engine Research, 2016, 17(8): 886-896.

[14] H Shahmohamadi, R Rahmani, H Rahnejat. Big end bearing losses with thermal cavitation flow under cylinder deactivation. Tribol. Lett., 2015, 57: 2(1-17). 
[15] G Z Wang, Y M Hao, W R Ma, et al. Thermo-elastohydrodynamic lubrication research of main bearings in IC engines. Chinese Internal Combustion Engine Engineering, 2010, 31(5): 63-68.

[16] K Kalogiannis, D R Merritt, O Mian, et al. Conrod bearings with an optimized narrow circumferential oil groove - simulated durability improvement for heavy-duty applications. Journal of Engineering for Gas Turbines and Power, 2015, 137: 1015101-1015109.

[17] N Lorenz, G Offner, O Knaus. Fast thermo-elasto-hydrodynamic modeling approach for mixed lubricated journal bearings in internal combustion engines. Proc IMechE Part J: Journal of Engineering Tribology, 2015, 229(8): 962-976.

[18] W Zhou, R Liao. Thermo-elasto-hydrodynamic mixed lubrication analysis of main bearings for high power-density diesel engine. Transactions of CSICE, 2016, 34(4): 370-378.

[19] A A Tabrizi, A H Kakaei. Different simulation models of connecting rod hydrodynamic bearing. SAE Paper 2009-01-1863, 2009.

[20] J Zhang, X Wang. Performance of main bearing in mixed lubrication of high power-density diesel engine. Transactions of CSICE, 2011, 29(1): 90-95.

[21] O Toshihiro, N Masatoshi. Lubrication analysis of a con-rod bearing using a cycle simulation of gasoline engines with AF variation. SAE Paper 201101-2118, 2011.

[22] Y Bi, Y Li, L Shen, et al. Lubrication property study of main bearing for turbocharged intercooled diesel engine. Chinese Internal Combustion Engine Engineering, 2012, 33(1): 87-92

[23] X Chen, B Zu, Y Xu, et al. Influence of high-turbocharged on performance of main bearing in diesel engine. Chinese Internal Combustion Engine Engineering, 2015, 36(3): 6-11.

[24] J Choi, S S Kim, S S Rhim, et al. Numerical modeling of journal bearing considering both elastohydrodynamic lubrication and multi-flexiblebody dynamics. International Journal of Automotive Technology, 2012, 13(2): 255-261.

[25] L Wei, S Duan, H Xing, et al. Thermo-elasto-hydrodynamic behavior of main bearings of marine diesel engines in mixed lubrication. Transactions of CSICE, 2013, 31(2): 183-191.
[26] L Wei, H Wei, S Duan, et al. Thermo-elasto-hydrodynamic mixed lubrication of main bearings of marine diesel engines, based on coupling between flexible engine block and crankshaft. Journal of Mechanical Engineering, 2014, 50(13): 97-105. (in Chinese).

[27] L Wei, H Wei, S Duan, et al. An EHD-mixed lubrication analysis of main bearings for diesel engine based on coupling between flexible whole engine block and crankshaft. Industrial Lubrication and Tribology, 2015, 67(2): 150-158.

[28] K Shao, CW Liu, F R Bi, et al. Analysis of hydrodynamic loads on performance characteristics of engine main bearings. Proc IMechE Part J: Journal of Engineering Tribology, 2015, 229(6): 667-676.

[29] X Zhao, A Huang, Z Hu, et al. Analysis of main bearing lubrication performance of high-power marine diesel engine under typical operating conditions. Chinese Internal Combustion Engine Engineering, 2015, 36(5): 128-133.

[30] J Yang, C Zhang, K Liu, et al. Lubrication analysis of main bearing for high speed gasoline engine based on non-stationary heat transfer. Vehicle Engine, 2016, 224(3): 40-46.

[31] J Sun, J Wang, C Gui. Whole crankshaft beam-element finite-element method for calculating crankshaft deformation and bearing load of an engine. Proc IMechE Part J: Journal of Engineering Tribology, 2009, 224: 299-303.

[32] J Sun, XY Zhao, H Wang. Lubrication analysis of crankshaft bearing considering crankshaft deformation. SAE Paper 2011-01-0613, 2011.

[33] G W Stachowiak, A W Batchelor. Engineering tribology. Burlington: Elsevier Butterworth-Heinemann, 2005.

[34] J Sun, XX Cai, L P Liu. Research on the effect of whole cylinder block on EHL performance of main bearings considering crankshaft deformation for internal combustion engine. ASME Journal of Tribology, 2010, 132(4): 044502-1-6.

\section{Submit your manuscript to a SpringerOpen ${ }^{\circ}$ journal and benefit from:}

- Convenient online submission

- Rigorous peer review

- Open access: articles freely available online

- High visibility within the field

- Retaining the copyright to your article

Submit your next manuscript at springeropen.com 